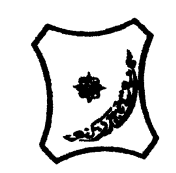

Bayero Journal of Pure and Applied Sciences, 12(1); 106 - 111

Received: February, 2018

Accepted: January, 2019

ISSN $2006-6996$

\title{
MECHANOCHEMICAL SYNTHESIS, CHARACTERIZATION AND ANTIMICROBIAL SCREENING OF METAL (II) COMPLEXES DERIVED FROM AMOXICILLIN
}

\author{
${ }^{1}$ Jibril S., ${ }^{2}$ Sani S., ${ }^{3}$ Kurawa M. A. and ${ }^{4}$ Shehu S. M. \\ ${ }^{1-4}$ Department of Chemistry, Aminu Saleh College of Education, P.M.B 44 Azare \\ ${ }^{2}$ Department of Pure and Applied Chemistry, Usman Danfodiyo University, P.M.B 2346, Sokoto \\ ${ }^{3}$ Department of Pure and Industrial Chemistry, Bayero University, P.M.B 3011, Kano \\ Correspondence author Email: shehuusmanjibril@yahoo.com
}

\begin{abstract}
Mechanochemical synthesis of Co(II), Fe(II), and Mn(II) amoxicillin complexes by simple grinding of metal (II) chlorides with amoxicillin. The mechanochemical products were characterized by solubility, melting points, conductivity values, magnetic moments and Infrared spectral studies. The IR spectral data of amoxicillin complexes the ligand acted as bidentate which coordinated to the metal ion through $v(C O O)$ and $v(C=0)$. The Job's method analyses suggested 1:2 metals to ligand ratio and molar conductivity values is in the range of 5.58-11.67 $\Omega^{-1} \mathrm{~cm}^{-1} \mathrm{~mol}^{1}$ indicating that the complexes behave as nonelectrolytes nature in DMSO. The complexes are all soluble in DMSO, while two are soluble in ethanol, DMF and methanol, one is not. The complexes decompose at a range of $217-278^{\circ} \mathrm{C}$ Indicating higher stability than their respective ligands. The magnetic moment values have proved that all the synthesized complexes are paramagnetic. The ligands and complexes were screened against three bacterial strains; Escherichia coli, Salmonella typhi and Staphylococcus aureus for antimicrobial activity. The results show that both the ligand and the complexes are active against the test bacteria; most complexes are active in all test concentration while others are only active at high concentration against bacteria.
\end{abstract}

Keywords: Mechanochemistry, Synthesis, Antibiotic, Transition Metals

\section{INTRODUCTION}

'Mechanochemistry' refers to reactions, normally of solids, induced by the input of mechanical energy, such as by grinding in ball mills(James et al.,2012). It is becoming more intensely studied partly because it can promote reactions between solids quickly and quantitatively, with either no added solvent or only nominal amounts. Historically it has been a sideline approach to chemical synthesis, and solutionbased methods have been adopted by default. However, mechanochemistry could in future become a more mainstream technique for two reasons.

Firstly, it is increasingly clear that is effective, and even advantageous, in ever-widening types of synthesis. Secondly, our current dependence on solvents appears increasingly unsustainable since it is wasteful of fossil-derived materials (e.g. $85 \%$ of chemicals used in the pharmaceutical industry are solvents and even if recycled typical recovery rates are only 50$80 \%$ ), environmentally problematic, hazardous and energy-demanding with regard to solvent production, purification and recycling (Jameset al.,2012).

Solvents can be present in the solid starting materials, such as in hydrated metal salts or in molecular solvates. There may even be (smaller) amounts of moisture in non-formally hydrated materials or in the atmosphere which aid the reaction (James et al., 2012). Under some experimental conditions, it is advantageous to add a few drops of solvent to the solids leading to so-called liquid-assisted grinding (LAG). In some cases, chemical reactions can also be initiated between a solid reactant and a liquid: in that case, the process is called kneading (Dubois et al.,2014).

This research work is aimed at synthesizing and characterizing metal (II) complexes of amoxicillin via machanochemical means. The objectives of this research include; Finding an alternative synthetic route for the synthesis of $\mathrm{Co}(\mathrm{II}), \mathrm{Mn}$ (II)and $\mathrm{Fe}$ (II) complexes of amoxicillin and characterizing them by Solubility, Melting/decomposition temperature, Conductive measurement, Magnetic susceptibility measurement and Infrared spectroscopy. 
BAJOPAS Volume 12 Number 1, June, 2019

Italso includes determining the antimicrobial activity of metal (II) complexes of amoxicillin in order to establish how metal-drug binding influence the activity of these drugs.

\section{MATERIALS AND METHODS}

All the reagents were of analytical grade and used without any further purification. The active pharmaceutical ingredient, amoxicillin was obtained from Sigma Aldrich. Metal salts used include metal (II) chlorides of $\mathrm{Co}, \mathrm{Fe}$, and $\mathrm{Mn}$.

All weighing was done using weighing balance model B154 METTLER TOLEDO. Molar conductance measurement was done using Jenwey conductivity meter model 4010 in DMSO. Jenwey 6305 UV-Visible Spectrophotometer was used for UV-absorbance measurement. Decomposition/ melting temperature were recorded using Stuart melting point apparatus SMP 10. Magnetic susceptibility measurement of the complexes was recorded using Magnetic Susceptibility balance of Sherwood Scientific Cambridge UK. The bacterium isolates; Escherichia Coli, Staphylococcus Aureus and Salmonella typhivere obtained and identified at Department of Microbiology, Bayero University Kano. Metal to Ligand ratio was determined using Job's method of continuous variation and Infrared spectra of ligands and complexes was recorded using Fourier Transform Infrared Spectrophotometer of Agilent Technologies.

\section{Synthesis of the Complexes}

The methods described by Kurawa and Yammama (2014) was adopted and modified for the synthesis of all the complexes. Each metal salts of $\left(1 \mathrm{mmol}, 0.238 \mathrm{~g}\right.$ of $\mathrm{CoCl}_{2} \cdot 6 \mathrm{H}_{2} \mathrm{O}, 0.3654 \mathrm{~g}$ of $\mathrm{FeCl}_{2} \cdot 4 \mathrm{H}_{2} \mathrm{O}$ and0.198g of $\mathrm{MnCl}_{2} \cdot 4 \mathrm{H}_{2} \mathrm{O}$ ) were mixed with $0.7308 \mathrm{~g}(2 \mathrm{mmol})$ of amoxicillin in $1: 2$ mole ratios. The mixture was ground in an agate mortar for $10-15$ minutes with $0.1 \mathrm{ml}$ drop of methanol to obtain a fine powder as product. The complexes were then dried in vacuum for 24hrs at $110^{\circ} \mathrm{C}$.

$\mathrm{MCl}_{2} \cdot \mathrm{nH}_{2} \mathrm{O}+2 \mathrm{Amox}$ Grinding $\left[\mathrm{Co}(\operatorname{amox})_{2} \mathrm{Cl}_{2}\right]$

(M=Fe, Mn \& Co)

$$
\operatorname{LAG}\left(\mathrm{CH}_{3} \mathrm{OH}\right)
$$

\section{Melting points}

DecompositionTemperature

Melting point of the ligand as well as decomposition temperature of the complexes were determined by introducing a pinch of each sample into a capillary tube and then inserted into Stuart melting point apparatus (SMP 10), the temperature at which the ligand melts and the complexes decomposed were recorded. Similar to the report of Waziri et al., (2017)

\section{Solubility Test}

The solubility's of the complexes were determined in different solvents ranging from polar to non-polar such as distilled water, methanol, ethanol, ethylacetate, chloroform, hexane, $\mathrm{CCL}_{4}$, dimethyl formamide (DMF) and dimethyl sulfoxide (DMSO), in which $0.1 \mathrm{~g}$ of each sample was tested in $10 \mathrm{ml}$ of each solvent. Kurawa and Yammama (2014)

Molar Conductance Measurement of the Ligand and their Complexes

Molar conductance of the ligand and the complexes were carried out in dimethyl sulfoxide (DMSO) by dissolving $0.001 \mathrm{~g}$ of each sample in $10 \mathrm{ml}$ of the solvent in a test tube, the electrode was inserted and the reading taken. Results obtained was compared with the one reported by (Mustapha et al., 2014)

\section{Magnetic Susceptibility Measurement}

The prepared metal complexes were introduced into the balance's capillary tube up to a given mark and the reading recorded using the magnetic susceptibility balance. The formula below was used to calculate the magnetic susceptibility $(\mathrm{Xg})$. That is; $\mathrm{Xg}=\mathrm{C} \times \mathrm{L}(\mathrm{R}-$ $\left.\mathrm{R}_{0}\right) / 10^{9} \mathrm{M}$

Where; $\mathrm{C}=1$, Constant of proportionality

$\mathrm{L}=$ sample length in $\mathrm{cm}$

$\mathrm{R}=$ reading obtained of the sample placed in tube

$\mathrm{R}_{0}=$ reading obtained of the pre-weight empty sample tube

$M=W_{2}-W_{1}$, mass of sample in the tube in $(g)$

The effective magnetic moment can then be calculated thus;

$\mathrm{Xm}=\mathrm{Xg} \mathrm{x}$ molar mass (molar magnetic moment)

Effective magnetic moment $\left(\mu_{\text {eff }}\right)=2.828(\mathrm{Xm} \mathrm{X}$ T) $)^{1 / 2}$

\section{$\mathrm{T}=$ Absolute temperature}

\section{Determination of Metal to Ligand ratio}

The number of ligand coordinated to the metal ion was determined using Job's method of continuous variation. $3.0 \mathrm{mmol}$ of Dimethylsulfoxide (DMSO) solution of the ligands and the metal chlorides were prepared. The following ligand to metal salt ratio (in $\mathrm{ml}$ ) 00:16, 01:15, 03:13, 05:11, 07:09, 09:07, 11:05, 13:03 were taken from the ligand solution and each of the metal chloride solution respectively.

A total volume of $16 \mathrm{ml}$ was maintained (in that order) throughout the process and the mole fraction of the ligand was calculated in each mixture. The solution of the metal salts were scanned (as blank) to find the wavelength of maximum absorbance $\left(\lambda_{\max }\right)$ for that particular metal ion (Skooget al., 2007). The machine was fixed at $\lambda_{\max }$ (in each case) before taken the absorbance values. 
The absorbance values were extrapolated against mole fraction of the ligand and the number of coordinated ligand (coordination number) was determined using the relation below:

$$
\bar{n}=x_{i} /\left(1-x_{i}\right)
$$

Where $\bar{n}=$ number of coordinated ligand and $\mathrm{X}_{\mathrm{i}}=$ mole fraction at maximum absorbance

\section{Antibacterial Activity Test}

According to method describe by (Yusha'u, \& Salisu, 2011). $0.02 \mathrm{~g}$ of ligand and metal (II) complexes each were dissolved in $1 \mathrm{ml}$ of Dimethyl sulfoxide (DMSO) to give stock solutions of three different concentrations $(5 \mu \mathrm{g}$, $10 \mu \mathrm{g}$ and $20 \mu \mathrm{g}$ ) which has been prepared by half serial doubling dilution method. They were placed on the surface of the culture media and incubated at room temperature for $48 \mathrm{hrs}$. Then in vitro antibacterial activity against Escherichia coli,Staphylococcus aureus and Salmonella typhi were carried out by agar-well diffusion method.
Standard was used to compare with the diameter of zone of inhibition produced by ligand and complexes.

\section{RESULT AND DISCUSSION}

The interaction between amoxicillin and the metal salts yielded coloured complexes of blue, brown and yellow cream for $\mathrm{Co}$ (II), Fe(II) and $\mathrm{Mn}$ (II) complexes respectively, which is similar with the result reported by Al-Mudhafar, (2009). Amoxicillin melted at a temperature of $189^{\circ} \mathrm{C}$ where as its interaction with metal (II) ions resulted complexes with decomposition temperatures of $278^{\circ} \mathrm{C}, 217^{\circ} \mathrm{Cand} 245^{\circ} \mathrm{C}$ for $\mathrm{Co}(\mathrm{II}), \mathrm{Fe}(\mathrm{II})$ and $\mathrm{Mn}$ (II) complexes respectively. This higher values than that of free Amoxicillin provide evidence of coordination of the ligand to the respective metal ions and also revealed the more stable nature of the complexes as shown in Table 1.These values are in agreement with similar metal (II) complexes reported by Waziri et al., (2017).

Table1: The Physical Properties of Amoxicillin and its Metal (II) Complexes

\begin{tabular}{cccc}
\hline Compounds & Colour & $\begin{array}{c}\text { Melting } \\
\text { point }\left({ }^{\circ} \mathbf{C}\right)\end{array}$ & $\begin{array}{c}\text { Decomposition } \\
\text { temperature }\left({ }^{\circ} \mathbf{C}\right)\end{array}$ \\
\hline Amoxicillin & White & 189 & 278 \\
Amox-Co(II) & Blue & - & 217 \\
Amox $-\mathrm{Fe}(\mathrm{II})$ & Brown & - & 245 \\
Amox $-\mathrm{Mn}(\mathrm{II})$ & Yellow cream & - & \\
\hline
\end{tabular}

Amoxicillin is soluble in methanol, ethanol, ethyl acetate, DMF and DMSO whereas its complexes are all insoluble in hexane and $\mathrm{CCL}_{4}$, all soluble in DMSO, soluble in some organic solvents and slightly soluble in other organic solvents (table 2). This is because, polar compounds are expected to be soluble in polar solvent, while non-polar compounds are expected to be soluble in non-polar solvent (like dissolves like), which is in agreement with results reported by Kurawa and Yammama (2014).

Table 2: Solubility of Amoxicillin and its Metal (II) Complexes

\begin{tabular}{|c|c|c|c|c|c|c|c|c|}
\hline $\begin{array}{c}\text { Ligand/ } \\
\text { Complexes }\end{array}$ & Methanol & Ethanol & Chloroform & $\begin{array}{c}\text { Ethyl } \\
\text { Acetate }\end{array}$ & Hexane & $\mathrm{CCL}_{4}$ & DMF & DMSO \\
\hline Amoxicillin & $\mathrm{S}$ & $\mathrm{S}$ & IS & $\mathrm{S}$ & IS & IS & $\mathrm{S}$ & $\mathrm{S}$ \\
\hline Amox-Co(II) & IS & $\mathrm{s}$ & $\mathrm{s}$ & IS & IS & SS & $\mathrm{s}$ & $\mathrm{S}$ \\
\hline $\begin{array}{l}\text { Amox - } \\
\text { Fe(II) }\end{array}$ & $S$ & IS & IS & IS & IS & IS & IS & $S$ \\
\hline $\begin{array}{l}\text { Amox - } \\
\text { Mn(II) }\end{array}$ & $\mathrm{S}$ & $\mathrm{S}$ & $\mathrm{S}$ & IS & IS & IS & $\mathrm{S}$ & $\mathrm{S}$ \\
\hline
\end{tabular}

Key: S-soluble, SS-slightly soluble, IS-insoluble

The suggestion of the likely geometry of complexes can also be provided by their magnetic moment in which magnetic susceptibility studies shows that complexes of $\mathrm{Co}(\mathrm{II}), \mathrm{Fe}(\mathrm{II})$ and $\mathrm{Mn}$ (II) were paramagnetic with the values range from 3.8-5.3BM (Table 3), in which all the values lies within the range that correspond to spin-only value magnetic moment for high spin octahedral geometry around $\mathrm{Co}(\mathrm{II})$, $\mathrm{Fe}(\mathrm{II})$ and $\mathrm{Mn}$ (II) ions respectively, which is similar with the one reported by (Adekunle 2013;Al-Noor et al., 2013; Anacona \& Rodriguel, 2004; Cotton \& Wilkinson, 1972 , p. 906).

The $\mu_{\text {eff }}$ values which are higher or lower than spin-only values for the respective metal (II) ion concerned may be due to spin-orbit coupling. 
BAJOPAS Volume 12 Number 1, June, 2019

Table 3: Effective Magnetic Moment and Molar Conductance of Metal (II) Amoxicillin Complexes

\begin{tabular}{ccccc}
\hline Complex & $\begin{array}{c}\text { Magnetic } \\
\text { Susceptibility(Xg) } \\
\left(\mathbf{( g}^{-\mathbf{1}}\right)\end{array}$ & $\begin{array}{c}\mathbf{X m} \\
\left(\mathbf{m o l}^{-\mathbf{1}}\right)\end{array}$ & $\begin{array}{c}\text { Effective } \\
\text { magnetic } \\
\text { moment (BM) }\end{array}$ & $\begin{array}{c}\text { Molar } \\
\text { Conductivity } \\
\left(\mathbf{\Omega}^{-\mathbf{1}} \mathbf{c m}^{\mathbf{2}} \mathbf{m o l}^{-\mathbf{1}}\right)\end{array}$ \\
\hline Amox-Co(II) & $7.8 \times 10^{-6}$ & $6.7 \times 10^{-3}$ & 3.8 & 11.67 \\
Amox -Fe(II) & $8.4 \times 10^{-6}$ & $7.2 \times 10^{-3}$ & 4.0 & 8.42 \\
Amox -Mn(II) & $1.7 \times 10^{-5}$ & $1.3 \times 10^{-2}$ & 5.3 & 5.58 \\
\hline
\end{tabular}

The molar conductance of metal (II) amoxicillin complexes measured at room temperature in $1 \times 10^{-3} \mathrm{M}$ in DMSO, the results obtained range from $5.58-11.67 \Omega^{-1} \mathrm{~cm}^{2} \mathrm{~mol}^{-1}$ respectively, which indicate few ionsor absence of ions. The results indicate non-electrolytes of all the complexes prepared due to the lower values. The results which is presented in Table 3 are in line with the report of (Adekunle 2013; El-waheed et aR008; Kurawa \& Yammama 2014; Mustapha et al., 2014; Refat et al., 2014; Shah \& Sharma 2013)
The IR spectra data of amoxicillin and its metal(II) complexes are presented in table 4 . The bands at $1689.54 \mathrm{~cm}^{-1}$ and $1774.50 \mathrm{~cm}^{-1}$ in the spectrum of free amoxicillin are assigned to $\mathrm{u}(\mathrm{C}=\mathrm{O})$ of amide and carboxylic acid respectively, as these shifted to different frequencies, $1599.51 \mathrm{~cm}^{-1}$ and $1778.83 \mathrm{~cm}^{-1}$, $1584.78 \mathrm{~cm}^{-1}$ and $1778.92 \mathrm{~cm}^{-1}, 1737.91 \mathrm{~cm}^{-1}$ and $1778.93 \mathrm{~cm}^{-1}$, for Amox-Co(II), Amox-Fe(II)and Amox-Mn(II) respectively, which suggested the coordination of carboxylic oxygen after deprotonating (Waziri et al., 2017)

Table 4: The IR Spectra Data of Amoxicillin and its Metal (II) complexes

\begin{tabular}{ccccc}
\hline Compounds & $\begin{array}{c}\mathbf{u}(\mathbf{C}=\mathbf{O}) \mathbf{c m}^{-\mathbf{1}} \\
\text { of amide }\end{array}$ & $\begin{array}{c}\mathbf{u}(\mathbf{C}=\mathbf{0}) \mathbf{c m}^{\mathbf{- 1}} \text { of } \\
\text { carboxylic acid }\end{array}$ & $\mathbf{u ( N - H ) \mathbf { c m } ^ { - 1 }}$ & $\mathbf{M - O}$ \\
\hline Amoxicillin & 1689.54 & 1774.50 & 3454.83 & - \\
Amox-Co(II) & 1599.51 & 1778.83 & 3409.70 & 575.26 \\
Amox-Fe(II) & 1584.78 & 1778.92 & 3361.89 & 579.09 \\
Amox-Mn(II) & 1737.91 & 1778.93 & 3324.66 & 553.00 \\
\hline
\end{tabular}

The bands at the range $575.26 \mathrm{~cm}^{-1}, 579.09 \mathrm{~cm}^{-}$ ${ }^{1}$ and $553.00 \mathrm{~cm}^{-1}$, in the spectra of amoxicillin complexes which could not traced to the free ligand spectrum is tentatively assigned to $\mathrm{M}-\mathrm{O}$ stretching frequencies for $\mathrm{Co}(\mathrm{II})$, $\mathrm{Fe}(\mathrm{II})$ and $\mathrm{Mn}$ (II). Similar amoxicillin complexes have been reported by other researchers (Imran et al, 2006; Waziri, et al, 2017; Reiss et al, 2015; AlMudhafar, 2009) using solution based synthesis. The octahedral geometry assumed agrees with IR spectrum and similar to the structures reported by Imran et al, (2006); Waziri, et al, (2017); Reiss et al, (2015) and Al-Mudhafar, (2009), supporting coordination of Amoxicillin to respective metal ions as shown in Table 4.

Estimation of the Metal to Ligand ratio was achieved by using Job's method of continuous variation, the results showing mole fraction of the Ligand and absorbance for the respective metal ions $\left(\mathrm{Co}^{2+}, \mathrm{Fe}^{2+}\right.$ and $\left.\mathrm{Mn}^{2+}\right)$ are presented in Table 5 as reported in the literature by (Skoog et al., 2007).

Table 5: Mole Fraction of the Ligand (Amoxicillin) and Absorbance of $\mathrm{Co}^{2+}, \mathrm{Fe}^{2+}$ and $\mathrm{Mn}^{2+}$ with the Ligand

\begin{tabular}{cccc}
$\begin{array}{c}\text { Mole fraction } X(\text { total } \\
\text { volume=9ml }\end{array}$ & $\begin{array}{c}\mathrm{Co}: \mathrm{L}_{2}{ }^{\prime} \\
\mathrm{max}=620 \mathrm{~nm}\end{array}$ & $\begin{array}{c}\mathrm{Fe}: \mathrm{L}_{2}{ }^{\prime} \\
\lambda \max =580 \mathrm{~nm}\end{array}$ & $\begin{array}{c}\mathrm{Mn}: \mathrm{L}_{2}{ }^{\prime} \\
\lambda \mathrm{max}=635 \mathrm{~nm}\end{array}$ \\
\hline 0.063 & 0.052 & 0.099 & 0.065 \\
0.188 & 0.071 & 0.100 & 0.066 \\
0.313 & 0.069 & 0.177 & 0.069 \\
0.438 & 0.070 & 0.212 & 0.077 \\
0.563 & 0.078 & 0.253 & 0.078 \\
0.688 & 0.073 & 0.224 & 0.070 \\
0.813 & 0.063 & 0.223 & 0.050 \\
0.938 & 0.052 & 0.127 & 0.040 \\
1.000 & 0.050 & 0.095 & 0.030 \\
\hline
\end{tabular}


The plot of absorbance against mole fraction in each case gives a curve with maximum absorbance corresponding to the ligand mole fractions which were used in calculating the number of coordinated ligand, which suggest $1: 2$ Metal-Ligand ratio in all the prepared complexes as reported by Anacona and Rodriguez(2004)

Table 6: Anti-bacterial Activity Test of Amoxicillin and its Metal (II) complexes

\begin{tabular}{ccccc}
\hline \multicolumn{5}{c}{ Inhibition Zones } \\
\hline Compounds & Concentration $(\mu \mathrm{g} /$ agar-well) & S. aureus $(\mathrm{mm})$ & E.coli $(\mathrm{mm})$ & S. typhi $(\mathrm{mm})$ \\
Amoxicillin & 5 & 24 & 18 & 20 \\
& 10 & 28 & 28 & 33 \\
Amox-Co(II) & 20 & 30 & 35 & 42 \\
& 5 & 23 & 19 & 18 \\
Amox-Fe(II) & 10 & 28 & 27 & 20 \\
& 20 & 38 & 33 & 31 \\
Amox-Mn(II) & 5 & - & - & 17 \\
& 10 & - & 10 & 24 \\
Standard & 20 & 29 & 15 & 37 \\
(Gentamycin) & 5 & 37 & 20 & 18 \\
Key: S. aureus $=$ Staphylococcus aureus & E. coli $=$ E scherichia coli & S. typhi=Salmonella typhi
\end{tabular}

Antimicrobial screening results shows that the amoxicillin complexes are active against all bacteria isolates in all concentration except Amox-Fe(II) which is inactive against Staphylococcus aureus and Escherichia coli at $5 \mu / a g a r-w e l l . ~ A m o x-M n(I I)$ has highest inhibition zone against Staphylococcus aureus at all concentrations with Amox-Fe(II) been least, as reported by Waziri et al., (2017).

On the basis of the analytical data obtained viz: melting point, conductivity measurement, magnetic susceptibility (effective magnetic moment), Job's method and FTIR spectroscopic studies, the structures proposed for the metal (II) complexes of amoxicillin would be;

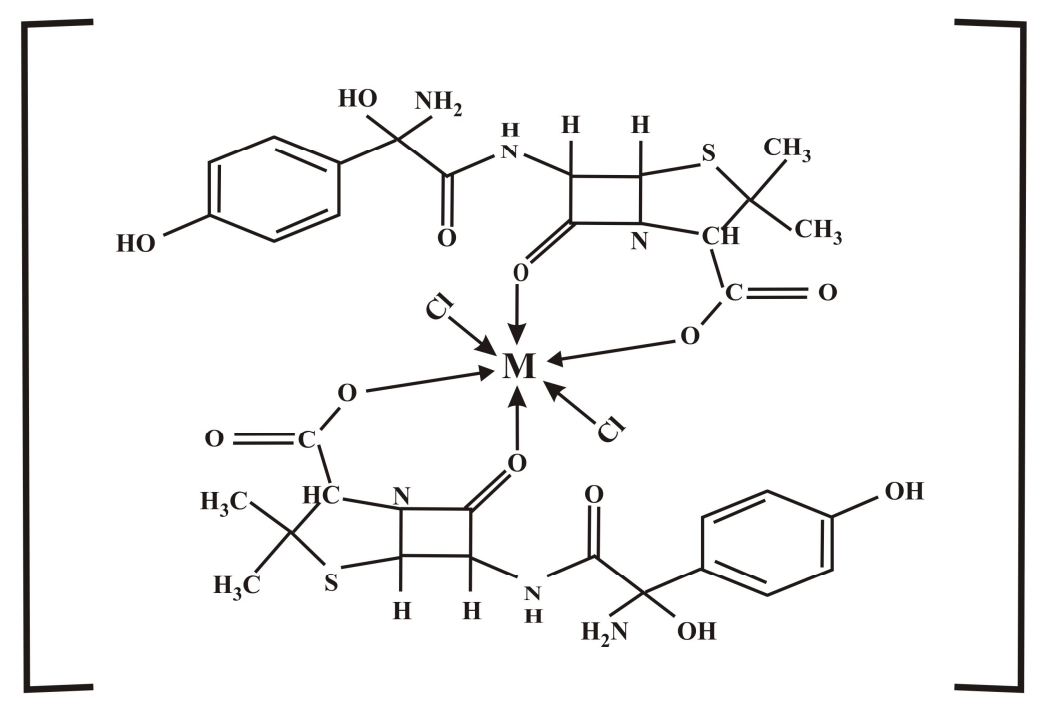

Fig 1: Proposed structure of Amoxicillin Complexes $\left(\mathrm{M}=\mathrm{Co}^{+2}, \mathrm{Fe}^{2+}\right.$ and $\left.\mathrm{Mn}^{+}\right)$

\section{CONCLUSION}

This research work has demonstrated the use of mechanochemical synthesis approach for the reliable synthesis of coordination metal (II) complexes of active pharmaceutical ingredient (API). It was discovered that, the solvent free solid-solid state can be used to obtain the same 
BAJOPAS Volume 12 Number 1, June, 2019

product as that obtained from conventional For all complexes, the obtained IR data, molar conductivity and effective magnetic moment values suggested the geometry and coordination of molecules of Amoxicillin to their respective metal ions. Amoxicillin coordinates $\mathrm{u}(\mathrm{COO})$ and $\mathrm{U}(\mathrm{C}=\mathrm{O})$ given rise to octahedral geometry.

\section{Contribution of Authors}

All the reported authors, Jibril S, performed the experimental work, Kurawa M. A supervised the

\section{REFERENCE}

Adekunle, F. A. O. (2013). Ni(II), Co(II), Mn(II) and $\mathrm{Zn}$ (II) Complexes of 5,6 -dihydro5,6-epoxy-1,10-phenanthroline, synthesis and spectroscopy studies. International Journal of Basic and Applied Science, 13(3): 6-10

Al-Mudhafar,M. M. J. (2009). Spectroscopic study for determination of amoxicillinusing cobalt(II) as complexing metal.Iraqi Journal of Pharmaceutical Science, 18(1), 5-11

Al-Noor, T. H., Ahmed.T., AL- Jeboori., \& Manhel, R. Aziz. (2013). Synthetic, spectroscopic and antibacterial studies of $\mathrm{Fe}(\mathrm{II}), \mathrm{Co}(\mathrm{II}), \mathrm{Ni}(\mathrm{II}), \mathrm{Cu}(\mathrm{II})$, and $\mathrm{Zn}(\mathrm{II})$ mixed ligand complexes of nicotinamide and cephalexin antibiotics. Chemistry and Materials Research, 3(3), 114-125

Anacona, J. R., \& Rodriguez, I. Y. (2004). Synthesis and antibacterial activity of cephalexin metal complexes. Journal of Coordination Chemistry, 57(15), 12631269

Cotton, F. A., \& Wilkinson, G. (1972). Advanced Inorganic Chemistry (3th ed.)Wiley. J., \& Sons(Eds). Interscience publisher. Newyork, London, Sydney, Toronto. pp. 590-906

Dubois, J., Colaco, M., \& Wouters, J. (2014). Mechanosynthesis, a method of choice in solid state synthesis. 21-30

El-wahed, M. G. A., Refat, M. S., \& ElMegharbel, S. M. (2008). Spectroscopic, thermal and biological studies of coordinationcompounds of sulfasalazine drug: $\quad \mathrm{Mn}(\mathrm{II}), \mathrm{Hg}(\mathrm{II}), \quad \mathrm{Cr}(\mathrm{III})$, $\mathrm{ZrO}(\mathrm{II}), \mathrm{VO}(\mathrm{II})$ and $\mathrm{Y}(\mathrm{III})$ transition metal complexes. Bull. Material Science, 32(2), 205-214

Imran, M., Iqbal, J., Mehmood, T., \& Latif, S. (2006). Synthesis, characterization and In viro Screening of Amoxicillin and its complexes with $\mathrm{Ag}(\mathrm{I}), \mathrm{Cu}(\mathrm{II}), \mathrm{Co}(\mathrm{II})$, $\mathrm{Zn}$ (II) and $\mathrm{Ni}(\mathrm{II})$. Journal of Biological Sciences, 6(5), 946-949

James, S. L., Adams, C. J., Bolm, C., Braga, D., Collier, P., Frinsic, T., ... \& Grepioni, F.(2012).Mechanochemistry: method.

research works. Sani $S$, assist in the interpretation of results while Shehu S. M contributed in the literature search. All the authors agreed with the final manuscript.

Conflict of Interest

All authors accepted and declare that, no conflict of interest.

Oppurtunity for new and cleaner synthesis. Chemical Society Reviews, 14(1), 413-447

Kurawa, M. A., \& Yammama, S. G. (2014). Solid state synthesis, characterization and biological activity of 4,4'-bipyridinium tetrachloronickelate (II) and 4,4'bipyridin dichloroniclate (II) complexes. ChemSearch Journal, 5(2), 59-65

Mustapha, A. N., Ndahi, N. P., Paul B. B. \& Fugu M. B. (2014). Synthesis, characterization and antimicrobial studies of metal (II) complexes of ciprofloxacin. Journal of Chemical and Pharmaceutical Research, 6(4), 588-593.

Refat, M. S., El-Korashy, S. A., \& Hussein, M. A. (2014). Ligational, spectroscopic (infrared and electronic) and thermal studies on the $\mathrm{Mn}(\mathrm{II}), \mathrm{Co}(\mathrm{II}), \mathrm{Fe}(\mathrm{II})$, and $\mathrm{Cu}$ (II) complexes with analgesis drugs. Journal of Canadian Chemical Transactions,2(1), 24-35

Reiss, A., Samide, A., Ciobanu, G., \& Dabuleanu, I. (2015). Synthesis, spectral characterization and thermal behaviour of new metal (II) complexes with schiff base derived from amoxicillin. Journal of Chilean Chemical Society, 60(3), 30743079

Shah, M., \& Sharma, A. (2013). Synthesis and characterization of some transition metal complexes derived from bidentate schiff base ligand. IOSR Journal of Applied Chemistry (IOSR-JAC), 3(5), 62-66

Skoog, A. D., Huller, F. J., \& Crouch, R. S. (2007). Principle of Instrumental Analysis (6 $6^{\text {th }}$ ed.). Robert, B. (Ed). Thomson Brooks/cole. Pp: 383-385

Waziri, I., Mala, G. A., Fugu, M. B., Isa, B., \& Umaru, U. (2017). Synthesis, spectral Characterization and antimicrobial activity of some metal complexes of mixed antibiotics. Chemistry Research Journal, 2(2), 46-52.

Yusha'u, M., \& Salisu F. U. (2011). Inhibition activity of detarium microcarpum extract on some clinical bacterial isolates. Biological and Enviromental Science Journal for the tropics, 8(4),113-117. 
BAJOPAS Volume 12 Number 1, June, 2019 